\title{
Macro Benthic Invertebrates Assemblage in Different Anthropogenic Activities Zone in Badagry Creek, South Western Nigeria
}

\author{
Bosede Omolara Ayo-Dada ${ }^{1 *}$ and Gbolagade Akeem Lameed ${ }^{2}$ \\ ${ }^{1}$ Fisheries Resources Department, Nigerian Institute for oceanography and Marine Research (NIOMR), Nigeria
}

${ }^{2}$ Department of Wildlife and Ecotourism University of Ibadan, Oyo-State, Nigeria

*Corresponding author: Bosede Omolara Ayo-Dadaa, Fisheries Resources Department, Nigerian Institute for oceanography and

Marine Research (NIOMR), P.O Box 12729, 3, Wilmot Point Road, off Ahmadu Bello Way, Victoria Island, Lagos, Nigeria

\begin{abstract}
ARTICLE INFO
Received: 慧 March 03, 2021

Published: 慧 March 15, 2021

Citation: Bosede Omolara Ayo-Dada, Gbolagade Akeem Lameed. Macro Benthic Invertebrates Assemblage in Different Anthropogenic Activities Zone in Badagry Creek, South Western Nigeria. Biomed J Sci \& Tech Res 34(3)-2021. BJSTR. MS.ID.005566.
\end{abstract}

Keywords: Macro Benthic Invertebrates; Anthropogenic Activities; Badagry Creek

Abbreviations: DW: Domestic Waste; DG: Dredging Zone; DO: Dissolved Oxygen; BOD: Biological Oxygen Demand; AQ: Aquaculture Zone

\section{ABSTRACT}

The assessment of Macro benthic ecosystem component, a habitat specific approach assess is strongly suggested, since a coastal water are characterized by highly variable physico chemical and hydro- morphological conditions. Badagry creek is one of the creeks that make up the Lagoon system in Lagos-State and pollution impacts through the anthropogenic activities around the creek that are generally attributed to the direct discharge of wastes (domestic and industrial), sand dredging and dredging discharge, which may affect the spatial distribution and composition of macro invertebrates' assemblages. Assessment of macro benthic invertebrates' assemblages and physico chemical parameters of Badgry creek were investigated between July 2017 to May 2018. Five anthropogenic activities zones were selected in accordance with their ecological importance from the nine study stations established in the upper, middle, and lower course of the creek. The five anthropogenic activities zones were Domestic waste (DW), Domestic waste combined Dredging (DW_DG), Dredging zone (DG), Aquaculture combined Dredging (AQ_DG), and Aquaculture zone (AQ). The diversity and dominance mean values during the wet season were $0.70 \pm 0.12,0.36 \pm 0.18,0.84 \pm 0.11,0.28 \pm 0.11$, and $0.55 \pm 0.11 ; 0.61 \pm 0.07,0.43 \pm 0.22,0.50 \pm 0.06,0.17 \pm 0.17,0.44 \pm 0.09$ for the DW,DW_DG, DG, AQ_DG, and AQ respectively.

The dry season mean values for diversity and dominance were $0.85 \pm 0.15,1.06 \pm 0.22$, $1.10 \pm 0.11,1.20 \pm 0.39$, and $1.07 \pm 0.25 ; 0.55 \pm 0.08,0.43 \pm 0.13,0.40 \pm 0.05,0.38 \pm$ 0.11 and $0.27 \pm 0.06$ for the DW, DW_DG, DG, AQ_DG, and AQ, respectively. Arthropoda insecta assemblages were relatively taxon poor and had low densities in the different anthropogenic activity's zones, its occurrence and abundance were registered only during the dry season. However, Gastropoda Mollusca had highest abundance and occurrences across the zones, the Gastropoda were tolerant to all the human disturbance activities defined during the sampling period. The $\mathrm{pH}$ value range (7.1-7.8) was moderate across the study zones, salinity recorded in this study range (2.41-6.66ppt) salinity was highest in May 2018 (26ppt) at station 7. The alkalinity values range $(20 \mathrm{mg} / \mathrm{L}-80 \mathrm{mg} / \mathrm{L})$. The mean values of Nitrate and phosphate $(0.18 \pm 0.22)$ and $(0.02 \pm 0.04)$ were low compare to the value of Sulphate $(11.83 \pm 34.83)$.

\section{Introduction}

Macro-invertebrates' species (benthos) are important ecosystem component within the ecosystem-based approach, due to their sessile, sedentary and relatively long life which are considered as important factors to be suitable and sensitive indicators of natural and anthropogenic variations Pearson [1]. A good indicator of temporal and chronic disturbances that has been proven is macro benthos Dauer [2]. Therefore, the assessment of the condition of benthic habitat is one of the evaluation criteria both 
in biological quality element, biodiversity, and sea floor integrity. Habitat transformation and pollution are problems encumbered by estuaries worldwide with serve risks to their ecological resilience Lotze, et al. [3]. The increasing pollution threaten the ecological services provided by estuaries, especially near urban centers where there is poor management of multiple impacts. Estuaries are priority areas for conservation and to be managed as marine reserves, despite their low environment quality. The sedimentary organic matter and pollutants on estuaries are important drivers of ecological changes observed on benthic assemblages. Urbanization and population growth are associated with pollution pressures that Nigerian aquatic systems are subjected to Edokpayi, et al. [4].

The seasonal distribution of rainfall, the lagoon and creeks experience seasonal flooding which introduces a lot of detritus, nutrients, as well as other land-based pollutants Ogunwenmo [5,6]. An assessment procedure for determining the condition of softsediment benthic habitats require the following aspects:

i. Habitat assignation of the samples (habitat approach),

ii. Reference or target conditions for the benthic parameters (reference approach) and

iii. The selection of indicator tools to assess the relative quality status (indicator approach).

A number of research works on benthic macro invertebrates community of lagoon systems of Southern Nigeria has been documented the hydrochemistry and macro benthic fauna characteristics of Ogbe creek Edopkayi, et al. [7] Benthic macrofauna of Epe Lagoon Uwadaie 2010, which has assisted in the taxonomic study and species identification in these lagoons. However, Badagry creek presents environmental gradients and considerable habitat heterogeneity resulting from human disturbance and natural environmental conditions, thereby providing an ideal testing ground to explore benthic assemblages and physiochemistry in their different structuring variation and biological communities. The present study aimed to assess the physicochemical parameters and microbenthic invertebrate assemblages across the different anthropogenic site in Badagry creek.

\section{Materials and Methods}

\section{Study Area}

Lagos State is located in South-Western Nigeria. Badagry creek (Figure 1) longitude $2^{\circ} 42^{\prime}$ and $3^{\circ} 23$ 'E and latitude $6^{\circ} 23^{\prime}$ and $6^{\circ}$ $28^{\prime} \mathrm{N}$. It is part of the $260 \mathrm{Km}$ - long lagoon system stretching from Cotonu in Republic of Benin to the Niger Delta in Nigeria, although centre in Lagos. It is bounded in the north by Egbado plateau and in the West by River Yewa via ologe lagoon. In the southern boundary is the Atlantic Ocean and in the east, bounded by the expanse of the mangrove swamp.

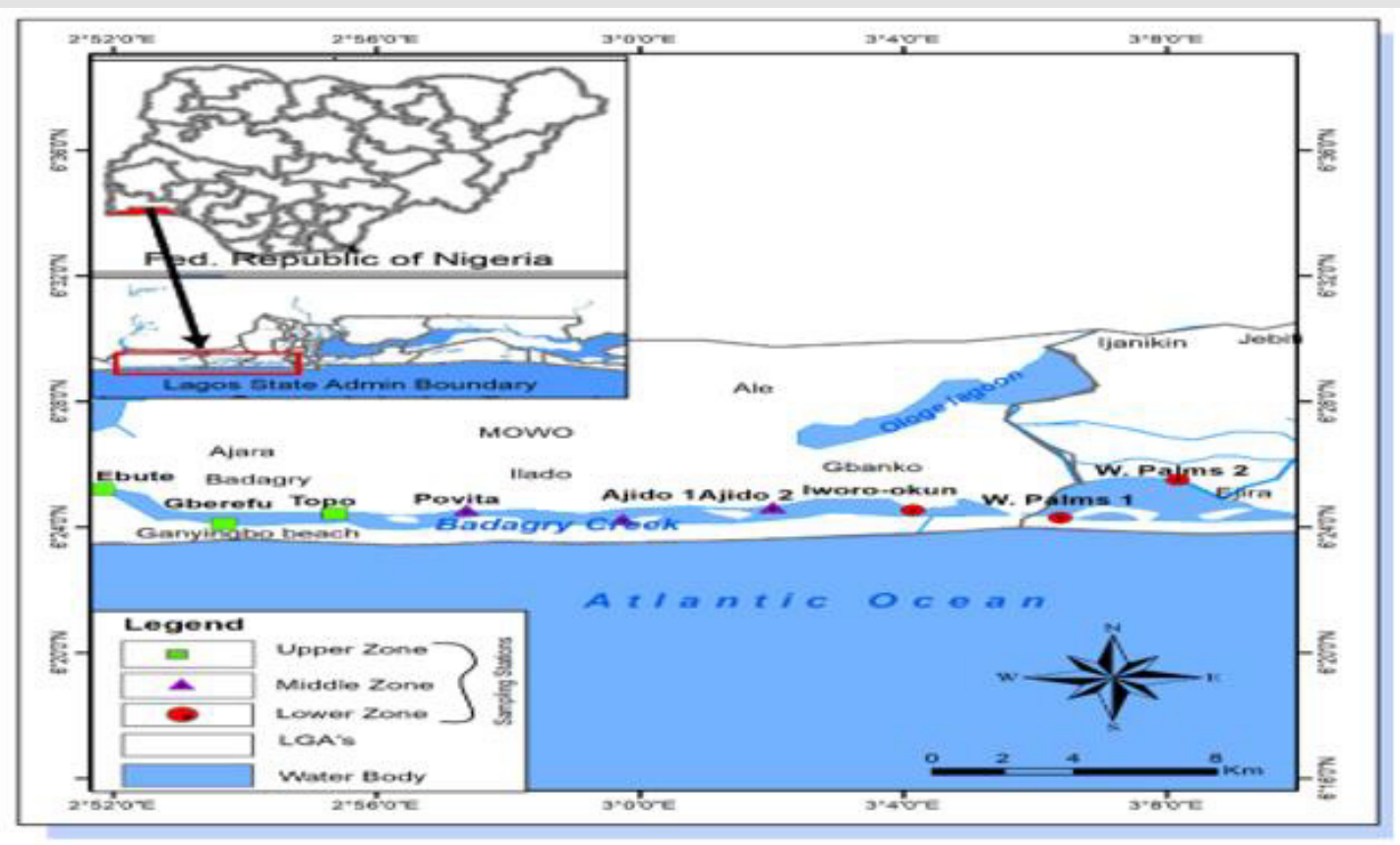

Figure 1: Map of Badagry creek showing the sampling stations.

\section{Macroinvertebrate Sampling}

Benthic macroinvertebrates were obtained from three quantitative replicates using a Van Veen grab (sampling surface area: $0.1 \mathrm{~m}^{2}$ ) of which the contents were sieved over $1 \mathrm{~mm}$ mesh sieve (prior to fixation). Invertebrates were preserved in 5\% formaldehyde, mixed with Rose Bengal for further analysis. After sieving all organisms were identified to the lowest possible taxonomic level (species level). 


\section{Sampling Stations}

Badagry creek was divided into three zones based on geographic locations and logistical characteristics, upper, middle, and lower zones Southwood $[8,9]$. In each of the zones, three stations were randomly selected and chosen as replicates, thus giving a total of nine stations. The nine stations were further grouped into five ecological sites, classifying sites based on comprehensive environmental disturbance score which was modified from Weigel [10]. The samples were taken at six regime sampling over a period of twelve months, monitoring stations. In spatially defined monitoring areas or areas characterized by certain human activities (dredging activities, domestic waste dumping, domestic sewage, boating activities, Aquaculture, and shrimp farm effluent). this resulted in a very good spatial coverage of benthos samples of the Badagry creek.

\section{Environmental Variables}

A multi-meter water checker (Horiba) model U-10 was used to determine the $\mathrm{pH}$, conductivity, salinity, Mercury in glass thermometer was used to determine the air and surface water temperature calibrated mercury in glass thermometer was dipped in water sample drawn for temperature. four chemical variables including nitrate $\left(\mathrm{NO}_{3}\right)$, Chloride, Phosphate, Sulphate; Dissolved oxygen (DO), Biological Oxygen Demand (BOD), they were all measured using colorimetric analysis by LaMotte test kit( NitratePhosphate) code 3119, USA, 2017; LaMotte Fresh water aquaculture test kit, Model AQ-2, 3633-03.

\section{Results}

\section{Benthic Macrofauna}

Diversity and Composition: Diversity and taxa richness differed significantly between five groups of Anthropogenic (human disturbance) zones. The total diversity mean value during the wet season was lower $(0.62 \pm 0.07)$ than the value recorded during the dry season $(1.05 \pm 0.08)$, on the contrary the total dominance mean value was higher in wet season $(0.47 \pm 0.04)$ than dry season $(0.41 \pm 0.04)$. Dredging (DG) zone had the highest mean diversity
$0.84 \pm 0.11$ during the period wet season, Domestic Waste (DW) zone had $0.70 \pm 0.12$ and Aquaculture combined Dredging activities (AQ_DG) zone had the least diversity $0.28 \pm 0.28$ during the wet season. The dry season had high mean diversity values across the various anthropogenic zones; AQ_DG had the highest mean diversity value $1.20 \pm 0.39$, DG zone had mean value $1.10 \pm 0.11$ and DW had the least diversity mean value $0.85 \pm 0.15$. However, during the wet season DW zone had highest dominance value $0.62 \pm 0.07$, the least was recorded in AQ_DG zone, the mean dominance value across the zones were $0.62 \pm 0.07,0.43 \pm 0.22,0.50 \pm 0.06,0.17 \pm 0.17$, and $0.44 \pm 0.09$ across DW, DW_DG, DG, AQ_DG and AQ respectively. The dry season registered the highest mean value dominance in DW zone, $0.55 \pm 0.08,0.44 \pm 0.13,0.40 \pm 0.05,0.38 \pm 0.11$, and $0.27 \pm 0.06$ across DW, DW_DG, DG, AQ_DG and AQ respectively.

The Gastropoda had the highest abundance across the different anthropogenic zones, malacostraca were the second most abundance across the various disturbance zones during the wet season. The dry season highest occurrence of biota than wet season; the Gastropoda had the highest abundance, malacostraca had second higher abundance and the insecta had the least occurrence among the anthropogenic zones, the highest occurrence of insecta was recorded in DG zone and least abundance insecta was recorded in DW zone.

\section{Physic-Chemical Parameters of The Water}

pH: The pH values (Figure 2) was between 6.8 and 8.3. the lowest value was recorded during the dry season in March 2018 at station 8 (whispering palms 1) under Aquaculture zone (AQ), while the highest value was documented at Aquaculture and Dredging (AQ_DG) zone. Higher alkaline environment was recorded during the dry season in January and wet season in May in Aquaculture and Dredging (AQ_DG) and Aquaculture zones. The mean $\mathrm{p}^{\mathrm{H}}$ values of zones (Table 1), Dredging zone (DG) recorded the lowest value ( 7.26 \pm 0.31 ), Domestic waste (DW) zone (7.40 \pm 0.38 ), Aquaculture AQ zone (7.45 \pm 0.43$)$, Domestic waste and Dredging DW_DG $(7.56 \pm 0.6)$ and highest in Aquaculture and Dredging AQ_DG zone $(7.7 \pm 0.41)$.
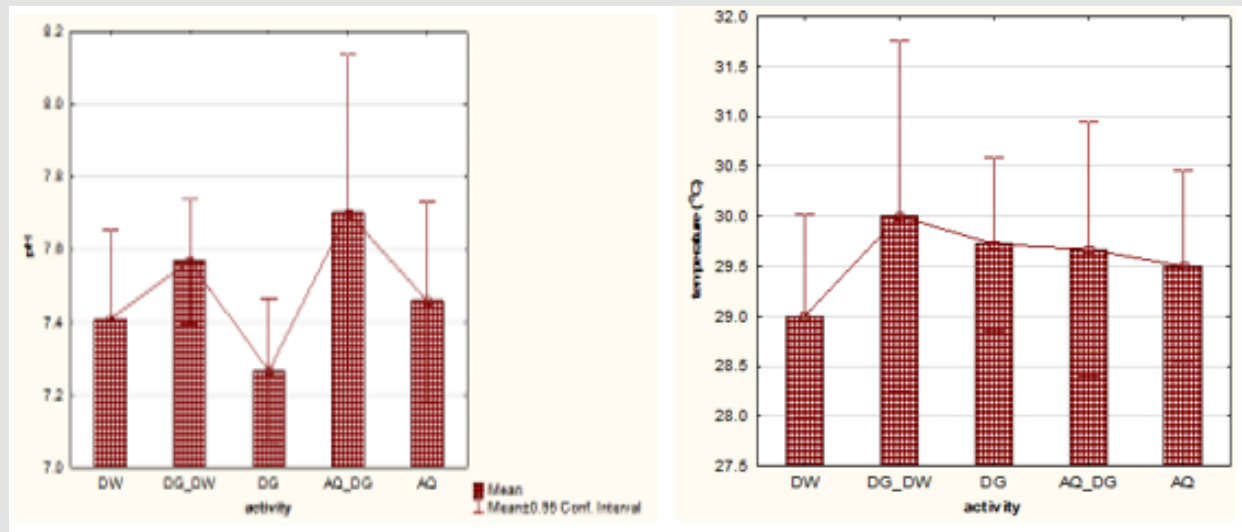

Figure 2: $\mathrm{pH}$ and Temperature across the Anthropogenic zones. 
Table 1: Description of the study area (stations).

\begin{tabular}{|c|c|c|c|c|c|}
\hline Water zone & Stations & Site & Anthropogenic Code & $\begin{array}{l}\text { Anthropogenic } \\
\text { Groups }\end{array}$ & Depth (m) \\
\hline \multirow{3}{*}{ Upper zone } & Station 1 & EBUTE & DW & Domestic waste & $2.58 \mathrm{~m}$ \\
\hline & Station 2 & GBEREFU & DW & Domestic Waste & $1.25 \mathrm{~m}$ \\
\hline & Station 3 & TOPO & DG_DW & $\begin{array}{c}\text { Dredging and } \\
\text { Domestic Waste }\end{array}$ & $1.91 \mathrm{~m}$ \\
\hline \multirow{3}{*}{ Middle zone } & Station 4 & POVITA & DG & Dredging & $1.61 \mathrm{~m}$ \\
\hline & Station 5 & AJIDO 1 & DG & Dredging & $1.78 \mathrm{~m}$ \\
\hline & Station 6 & AJIDO 2 & DG & Dredging & $1.85 \mathrm{~m}$ \\
\hline \multirow{3}{*}{ Lower zone } & Station7 & IWORO & AQ_DG & $\begin{array}{l}\text { Aquaculture and } \\
\text { Dredging }\end{array}$ & $1.52 \mathrm{~m}$ \\
\hline & Station 8 & WHISPERING PALMS 1 & AQ & Aquaculture & $1.22 \mathrm{~m}$ \\
\hline & Station 9 & WHISPERING PALMS 2 & AQ & Aquaculture & $1.65 \mathrm{~m}$ \\
\hline
\end{tabular}

Conductivity: The electric conductivity mean values recorded the lowest in Dredging and Domestic waste zone (DG_DW) (35.40 \pm 0.5129$)$, Domestic waste (DW) value $(4645 \pm 4976)$, it increased drastically in (DG) Dredging zone (92.83 \pm 0.12$)$, Aquaculture zone (AQ) (104.46 \pm 0.129$)$, the highest value was observed in Aquaculture and Dredging zone (AQ_DG) (133.73 \pm 0.18$)$.The Domestic waste zone in had the lowest value during the wet season, zone under Aquaculture and Dredging (AQ_DG) had the highest value in the same season; while in the dry season, zones under Domestic waste (DW), and Dredging and Domestic waste(DG_DW) were relatively low compared with zones under Dredging (DG),Aquaculture and Dredging(AQ_DG) and Aquaculture(AQ).

Secchi Disc Transparency: Spatially (zone) lowest mean transparency (Figures 3-5) was lowest at Dredging and Domestic waste (DG_DW) $(0.67 \pm 0.2)$, Domestic waste (DW) zone mean value $(0.89 \pm 0.42)$, while the highest mean value was recorded at Aquaculture and Dredging zone (AQ_DG) $0.97 \pm 0.49 \mathrm{~m}$. The total average mean of transparency (Tables 2-4). The analysis of variance transparency means values showed no significant value $(\mathrm{P}>0.05)$ among zones (Figures 4-7).

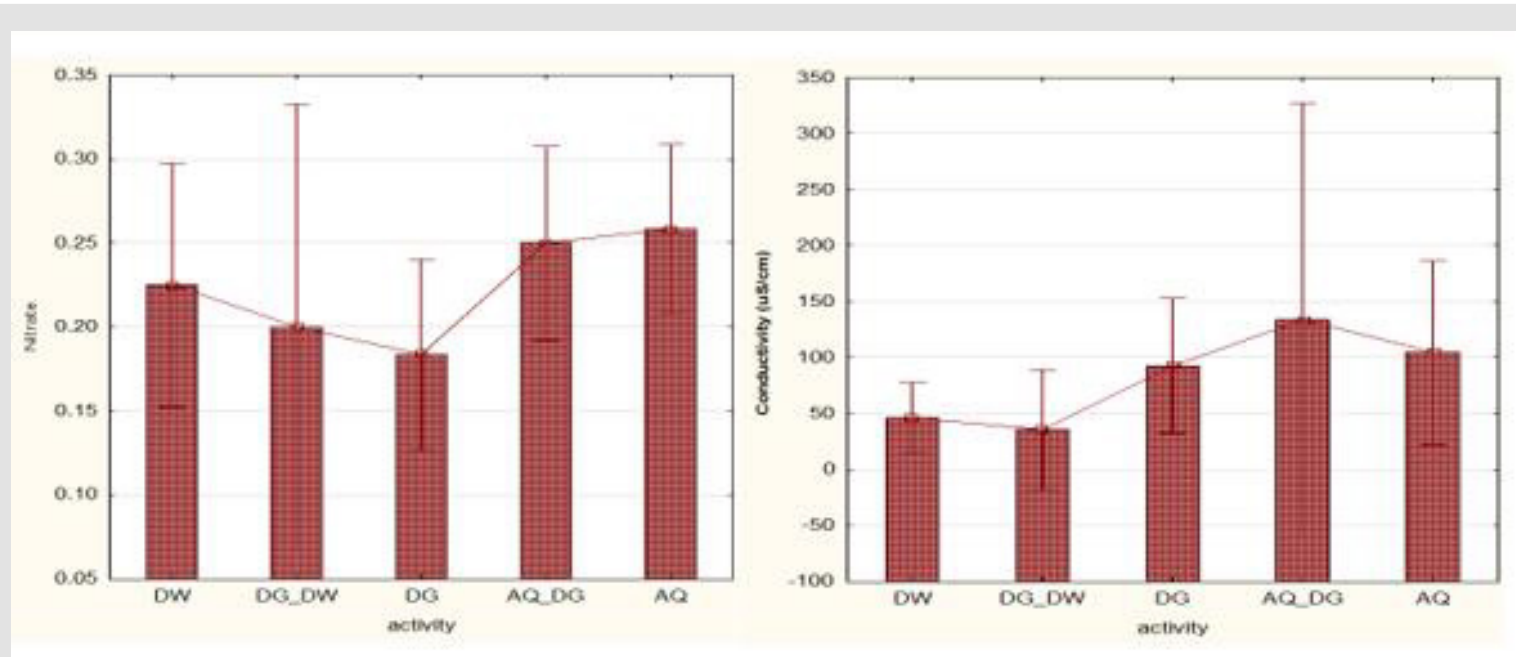

Figure 3: Nitrate and Conductivity Across the different Anthropogenic. 


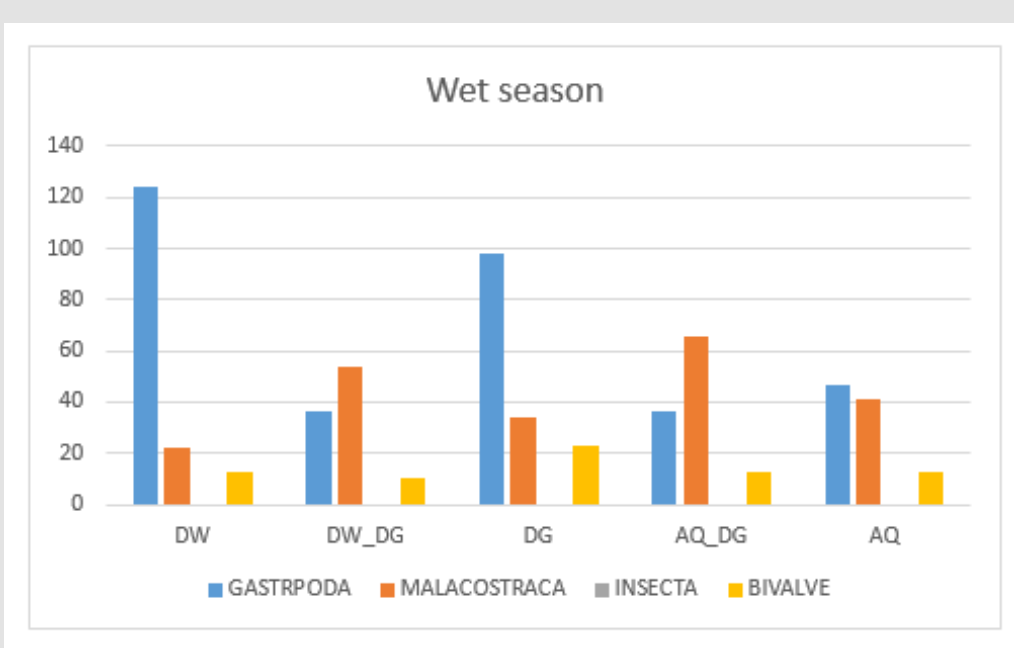

Figure 4: Percentage abundance of macrofauna during wet season in the study area.

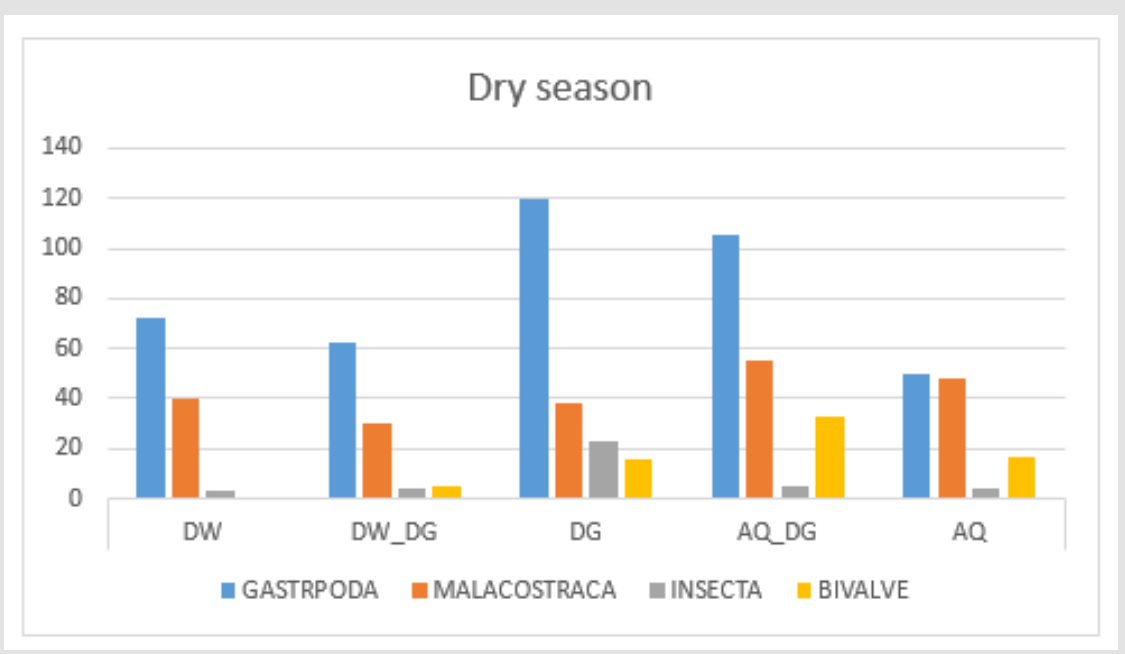

Figure 5: Percentage occurrence during the dry season in the study area.

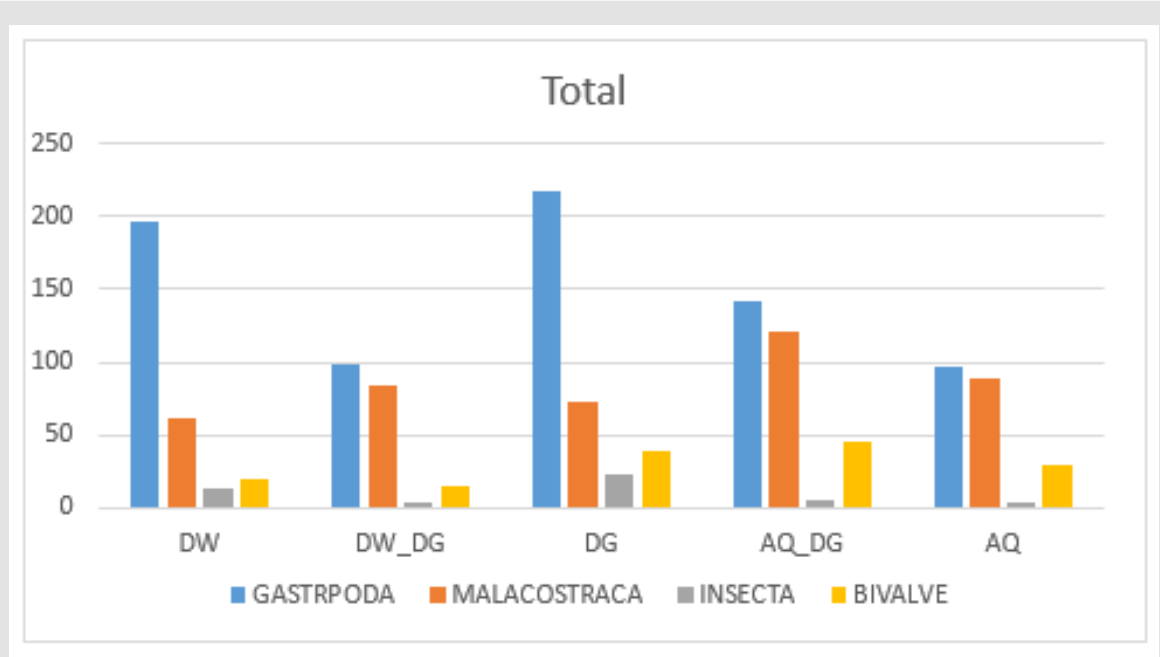

Figure 6: Overall percentage abundance of benthic macrofauna in the study area. 


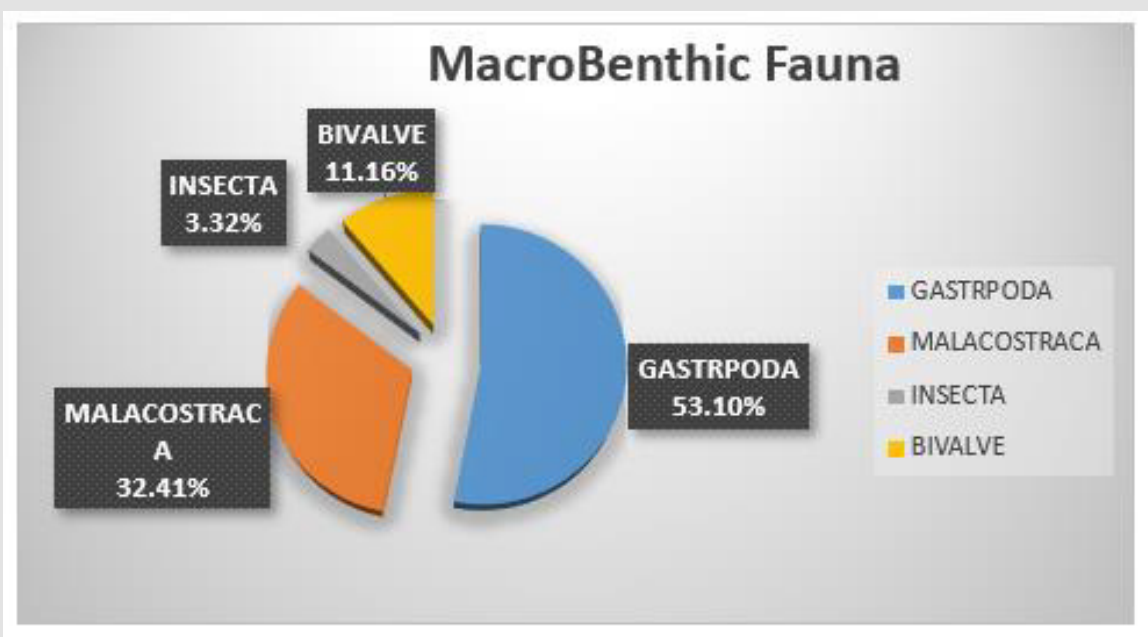

Figure 7: Overall percentage abundance of benthic macrofauna in the study area.

Table 2: Abundance and occurrence of macro invertebrates in their different anthropogenic zones in Badagry creek.

\begin{tabular}{|c|c|c|c|c|c|c|c|c|c|c|c|c|}
\hline \multirow[b]{2}{*}{ Fauna } & \multicolumn{2}{|c|}{ DW } & \multicolumn{2}{|c|}{ DW_DG } & \multicolumn{2}{|c|}{ DG } & \multicolumn{2}{|c|}{ AQ_DG } & \multicolumn{2}{|c|}{$\mathbf{A Q}$} & \multicolumn{2}{|c|}{ Total } \\
\hline & $S$ & $\mathbf{N}$ & $S$ & $\mathbf{N}$ & $\mathbf{S}$ & $\mathbf{N}$ & $S$ & $\mathbf{N}$ & $\mathbf{S}$ & $\mathbf{N}$ & $S$ & $\mathbf{N}$ \\
\hline \multicolumn{13}{|c|}{$\begin{array}{c}\text { Mollusca } \\
\text { Gastropoda }\end{array}$} \\
\hline Pachychilidae & 0 & 0 & 2 & 31 & 2 & 55 & 0 & 0 & 1 & 10 & 2 & 96 \\
\hline Thiaridae & 1 & 116 & 1 & 38 & 3 & 75 & 1 & 98 & 1 & 37 & 3 & 364 \\
\hline Neritidae & 0 & 0 & 1 & 29 & 1 & 30 & 1 & 15 & 1 & 10 & 1 & 84 \\
\hline $\begin{array}{l}\text { Potamidielae \& } \\
\text { Litternnidae }\end{array}$ & 1 & 52 & 0 & 0 & 2 & 28 & 2 & 10 & 1 & 15 & 2 & 53 \\
\hline Litternnidae & 1 & 8 & 0 & 0 & 1 & 10 & 1 & 9 & 1 & 15 & 1 & 42 \\
\hline Planorbidea & 1 & 10 & 0 & 0 & 1 & 20 & 1 & 9 & 1 & 10 & 2 & 49 \\
\hline \multicolumn{13}{|c|}{$\begin{array}{c}\text { Athropoda } \\
\text { Malacostraca }\end{array}$} \\
\hline Paguroidea/ crustacea & 1 & 28 & 1 & 30 & 1 & 20 & 1 & 35 & 1 & 29 & 1 & 142 \\
\hline Palaemonidae & 1 & 20 & 1 & 24 & 1 & 19 & 1 & 25 & 1 & 20 & 1 & 108 \\
\hline Sesarmidae & 1 & 14 & 1 & 18 & 1 & 20 & 1 & 30 & 1 & 10 & 1 & 92 \\
\hline \multicolumn{13}{|c|}{$\begin{array}{l}\text { Mollucsa } \\
\text { Bivalve }\end{array}$} \\
\hline Veneridae & 1 & 9 & 1 & 15 & 1 & 17 & 1 & 25 & 1 & 15 & 1 & 81 \\
\hline Birthynidae \& Assimeidae & 1 & 5 & 0 & 0 & 1 & 12 & 0 & 0 & 1 & 15 & 1 & 32 \\
\hline Mytiloida & 1 & 7 & 0 & 0 & 1 & 10 & 1 & 20 & 0 & 0 & 1 & 37 \\
\hline \multicolumn{13}{|c|}{$\begin{array}{l}\text { Euarthropoda } \\
\text { Insecta }\end{array}$} \\
\hline Libelluidae & 1 & 8 & 1 & 8 & 1 & 15 & 1 & 5 & 1 & 2 & 1 & 38 \\
\hline endopterygota & 1 & 5 & 1 & 7 & 1 & 8 & 0 & 0 & 1 & 2 & 1 & 22 \\
\hline Total & 12 & 282 & 10 & 212 & 19 & 354 & 12 & 312 & 14 & 210 & 20 & 1318 \\
\hline
\end{tabular}

Note: $S=$ No. of Taxa, $\mathrm{N}=$ No. of individual 
Table 3: Ranking of the numerically Abundant Macro Benthic Organism in Badagry Creek (July 2017-May 2018).

\begin{tabular}{|c|c|c|c|c|c|c|}
\hline \multirow[b]{2}{*}{ Species } & \multicolumn{3}{|c|}{$\begin{array}{l}\text { Dry Season (November 2017, January 2018,March } \\
\text { 2018) }\end{array}$} & \multicolumn{3}{|c|}{ Wet Season (July 2017, September 2017 and May 2018) } \\
\hline & No/ $10 \mathrm{~m}^{2}$ & $\%$ of total no & Abundance ranking & No $/ \mathrm{m}^{2}$ & $\%$ of total no & Abundance ranking \\
\hline Pachymelania aurita & 134 & 18.36 & $1^{\text {st }}$ & 128 & 20.31 & $1^{\text {st }}$ \\
\hline Pachymelania fusca & 75 & 10.27 & $2^{\text {nd }}$ & 50 & 7.94 & $4^{\text {th }}$ \\
\hline Neritina glabrata & 40 & 5.48 & $6^{\text {th }}$ & 15 & 2.38 & $14^{\text {th }}$ \\
\hline Potadoma moerchi & 30 & 4.10 & $9^{\text {th }}$ & 15 & 2.38 & $14^{\text {th }}$ \\
\hline Pirenell conica & 10 & 1.37 & $17^{\text {th }}$ & 14 & 2.22 & $17^{\text {th }}$ \\
\hline Clibinarius africanus & 70 & 9.59 & $3^{\text {rd }}$ & 75 & 11.90 & $2^{\text {nd }}$ \\
\hline Sesarma hilzardi & 62 & 8.49 & $4^{\text {th }}$ & 60 & 9.52 & $3^{\text {rd }}$ \\
\hline Macrobrachium rosenbergii & 52 & 7.12 & $5^{\text {th }}$ & 45 & 7.14 & $5^{\text {th }}$ \\
\hline Callinectes amnicola & 26 & 3.56 & $10^{\text {th }}$ & 31 & 4.92 & $7^{\text {th }}$ \\
\hline Brachyodontes tenuistriatus & 39 & 5.34 & $7^{\text {th }}$ & 35 & 5.56 & $6^{\text {th }}$ \\
\hline Brachyodontes puniceus & 15 & 2.05 & $15^{\text {th }}$ & 20 & 3.17 & $11^{\text {th }}$ \\
\hline Crassostrea gasar & 17 & 2.33 & $14^{\text {th }}$ & 17 & 2.69 & $13^{\text {th }}$ \\
\hline septaria barbonica & 35 & 4.79 & $7^{\text {th }}$ & 30 & 4.76 & $8^{\text {th }}$ \\
\hline tivela tripla $L$ & 30 & 4.11 & $8^{\text {th }}$ & 25 & 3.97 & $9^{\text {th }}$ \\
\hline libellulidae & 20 & 2.74 & $11^{\text {th }}$ & 0 & 0 & $19^{\text {th }}$ \\
\hline megasoma spp & 19 & 2.60 & $13^{\text {th }}$ & 0 & 0 & $20^{\text {th }}$ \\
\hline Assiminea bifasciata & 20 & 2.73 & $12^{\text {th }}$ & 24 & 3.80 & $10^{\text {th }}$ \\
\hline Melanoides mueruensis & 15 & 2.05 & $15^{\text {th }}$ & 20 & 3.17 & $11^{\text {th }}$ \\
\hline pitaria tumens (comelin) & 10 & 1.37 & $17^{\text {th }}$ & 15 & 2.38 & $16^{\text {th }}$ \\
\hline Amphipod & 10 & 1.37 & $17^{\text {th }}$ & 5 & 0.79 & $18^{\text {th }}$ \\
\hline
\end{tabular}

Table 4: Macro Benthic seasonal Diversity indices at the different Anthropogenic zones in Badagry creek.

\begin{tabular}{|c|c|c|}
\hline SEASON & ZONES & $\mathrm{MEAN} \pm \mathrm{SE}$ \\
\hline \multirow{6}{*}{ SHANNON/ WET } & DOMESTIC WASTE (DW) & $0.6950 \pm 0.12$ \\
\hline & Domestic waste and Dredging (DG_DW) & $0.3567 \pm 0.18$ \\
\hline & Dredging (DG) & $0.8356 \pm 0.11$ \\
\hline & Aquaculture and Dredging(AQ_DG) & $0.2833 \pm 0.28$ \\
\hline & Aquaculture (AQ) & $0.5500 \pm 0.11$ \\
\hline & Total & $0.6263 \pm 0.07$ \\
\hline \multirow{6}{*}{ DOMINANCE } & DW & $0.6117 \pm 0.07$ \\
\hline & DG_DW & $0.4308 \pm 0.22$ \\
\hline & DG & $.5022 \pm 0.06$ \\
\hline & AQ_DG & $0.1700 \pm 0.17$ \\
\hline & $\mathrm{AQ}$ & $.4417 \pm 0.09$ \\
\hline & Total & $.4681 \pm 0.04$ \\
\hline \multirow{6}{*}{ SHANNON/ DRY } & DW & $.8517 \pm 0.15$ \\
\hline & DG_DW & $1.0667 \pm 0.22$ \\
\hline & DG & $1.1000 \pm 0.11$ \\
\hline & AQ_DG & $1.2000 \pm 0.39$ \\
\hline & $\mathrm{AQ}$ & $1.0733 \pm 0.25$ \\
\hline & TOTAL & $1.0463 \pm 0.08$ \\
\hline \multirow{3}{*}{ DOMINANCE } & DW & $0.5500 \pm 0.08$ \\
\hline & DG_DW & $0.4367 \pm 0.13$ \\
\hline & DG & $.3978 \pm 0.05$ \\
\hline
\end{tabular}




\begin{tabular}{|l|c|c|}
\hline \multirow{2}{*}{} & AQ_DG & $.3833 \pm 0.11$ \\
\cline { 2 - 3 } & AQ & $0.2733 \pm 0.06$ \\
\hline & TOTAL & $0.4067 \pm .03$ \\
\hline
\end{tabular}

Salinity: The salinity mean values were $2.41 \pm 0.41,2.83 \pm 0.49$, $2.44 \pm 0.34,6.66 \pm 0.96$, and 3.25 \pm 0.32 PSU respectively for Domestic waste zone( DW), Dredging and Domestic waste zone (DG_DW), Dredging zone (DG), Aquaculture and Dredging zone (AQ_DG), and Aquaculture zone (AQ). The highest mean value was recorded in Aquaculture and Dredging zone (AQ_DG) also wet season had the highest value of salinity.

Alkalinity: Alkalinity value throughout the study period was between $20 \mathrm{mgL}^{-1}$ and $80 \mathrm{mgL}^{-1}$ the least value was recorded in Dredging zone (DG) $41.55 \pm 15.36 \mathrm{mgL}^{-1}$ and highest value in Aquaculture and Dredging zone (AQ_DG). The mean alkalinity was $44.5 \pm 8.18 \mathrm{mgL}^{-1}, \quad 45.66 \pm 10.61 \mathrm{mgL}^{-1}, \quad 41.55 \pm 15.36 \mathrm{mgL}^{-1}$, $56.66 \pm 16.03 \mathrm{mgL}^{-1}$, and $52.41 \pm 19.77 \mathrm{mgL}^{-1}$ respectively in Domestic waste (DW) zone, Dredging and Domestic waste(DG_DW) zone, Dredging (DG) zone, Aquaculture and Dredging (AQ_DG) zone, and Aquaculture $(\mathrm{AQ})$ zone.

Water Depth: The water depth observed during the study period were between $0.72 \mathrm{~m}$ and $3.24 \mathrm{~m}$. Mean depth values of the zones were $1.93 \pm .77 \mathrm{~m}, 1.47 \pm 0.88 \mathrm{~m}, 1.86 \pm 0.91,1.48 \pm 0.66 \mathrm{~m}$ and $1.37 \pm 0.55 \mathrm{~m}$ respectively in Domestic waste (DW) zone, Dredging and Domestic waste(DG_DW) zone, dredging (DG) zone, Aquaculture and Dredging (AQ_DG) zone, and Aquaculture (AQ) zone. The highest value was recorded in Domestic waste (DW) zone , followed by the Dredging (DG) zone.

\section{Nutrients}

Nitrate: Nitrate mean concentration values varied across three zones, dredging zone (DG) $0.18 \pm 0.11 \mu \mathrm{mol} / \mathrm{L}$, Dredging and Domestic waste zone(DG_DW) $0.2 \pm 0.12 \mu \mathrm{mol} / \mathrm{L}$, Domestic waste

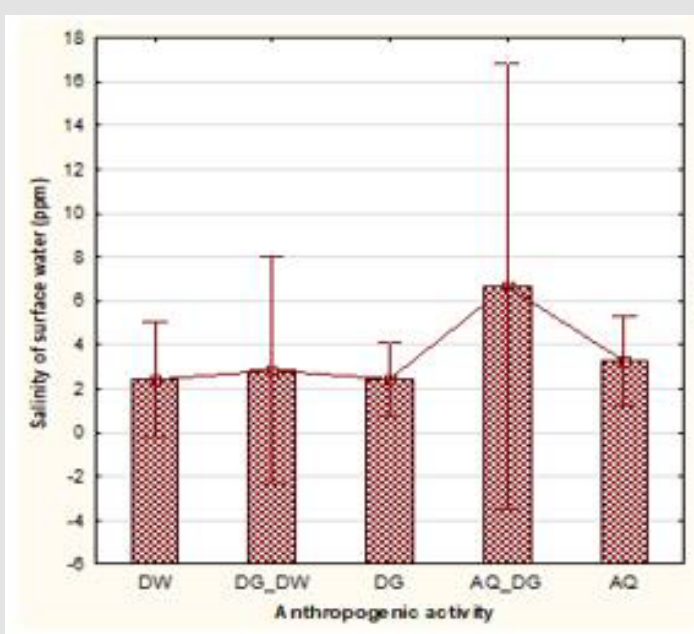

zone (DW) $0.22 \pm 0.11 \mu \mathrm{mol} / \mathrm{L}$, while and Aquaculture zone (AQ) and Aquaculture combined Dredging zone (AQ_DG) had the same mean values of $0.25 \pm 0.05 \mu \mathrm{mol} / \mathrm{L}$ and $0.25 \pm 0.07 \mu \mathrm{mol} / \mathrm{L}$.

Phosphate: Phosphate mean concentration values were the same value $0.02 \pm 0.02 \mu \mathrm{mol} / \mathrm{L}$ across three zones, Domestic waste zone (DW), Dredging zone (DG), and Aquaculture zone (AQ) respectively, it varied in combined activities zones Dredging and Domestic waste (DG_DW) $0.04 \pm 0.07 \mu \mathrm{mol} / \mathrm{L}$ and Aquaculture and Dredging zone (AQ_DG) $0.03 \pm 0.03 \mu \mathrm{mol} / \mathrm{L}$.

Sulphate: Sulphate concentrations varied from different Anthropogenic zones, the Dredging combined Domestic waste zone (DG_DW) had the least mean value $(11.83 \pm 4.35 \mu \mathrm{mol} / \mathrm{L})$, Aquaculture zone $(\mathrm{AQ})$ recorded mean value $(16.16 \pm 5.14 \mu \mathrm{mol} / \mathrm{L})$, Domestic waste zone (DW) had $(20.5 \pm 4.98 \mu \mathrm{mol} / \mathrm{L})$, Dredging zone (DG) $(31.27 \pm 15.83 \mu \mathrm{mol} / \mathrm{L})$, the highest mean value was recorded in Aquaculture combined Dredging zone (AQ_DG) $(34.83 \pm 33.12 \mu \mathrm{mol} / \mathrm{L})$. The highest mean value was recorded during the dry season $24.40 \pm 15.58 \mu \mathrm{mol} / \mathrm{L}$ and wet season recorded $(23.11 \pm 16.98 \mu \mathrm{mol} / \mathrm{L})$.

Chloride: Chloride concentration mean value varied from $(616.66 \pm 16.3)$ at Dredging combined Domestic waste zone (DG_ DW) to $(793.33 \pm 27.3)$ in Aquaculture combined Dredging zone (AQ_DG). The mean values among various zones were, $656 \pm 87.65$, $616.66 \pm 16.32, \quad 663 \pm 1.87, \quad 793.33 \pm 27.3$, and $701.66 \pm 45.49$ respectively, across Domestic waste zone (DW), Dredging combined Domestic waste zone (DG_DW), Dredging zone (DG), Aquaculture combined dredging zone (AQ_DG) and Aquaculture zone (AQ). The highest mean value was recorded in Aquaculture combined Dredging zone (AQ_DG) (793.33 \pm 27.3$)$ (Figures 6-11).

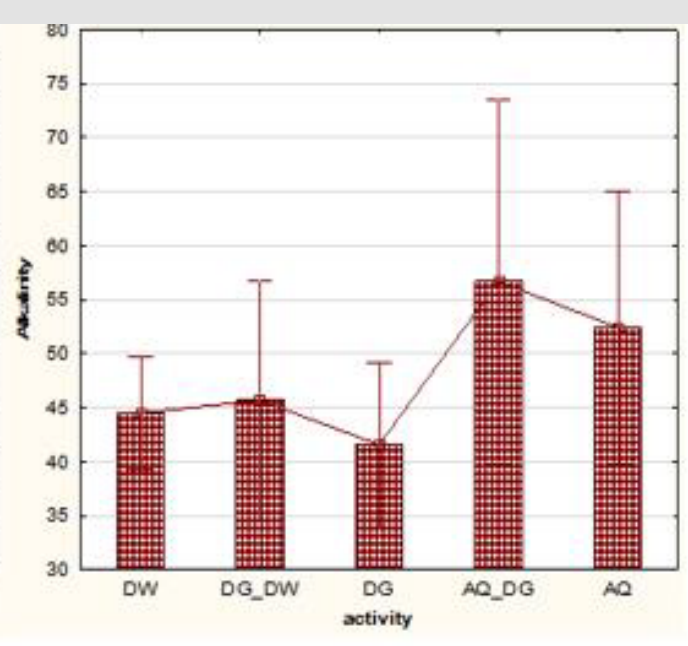

Figure 8: Salinity and Alkalinity across the Anthropogenic zones. 

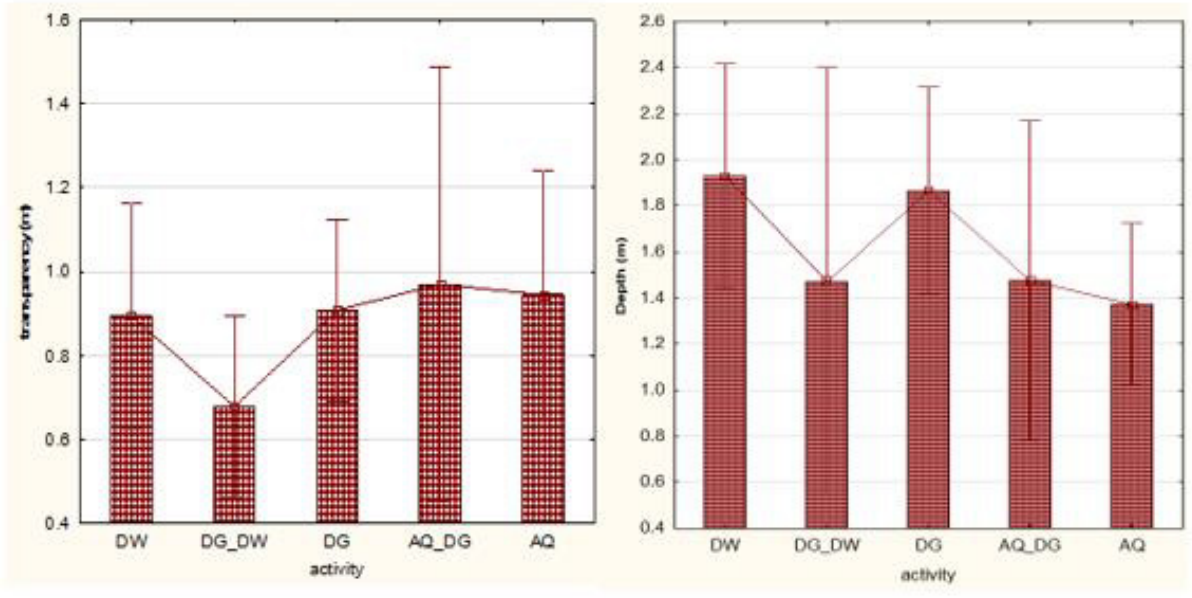

Figure 9: Transparency and Depth Across the different Anthropogenic zones.
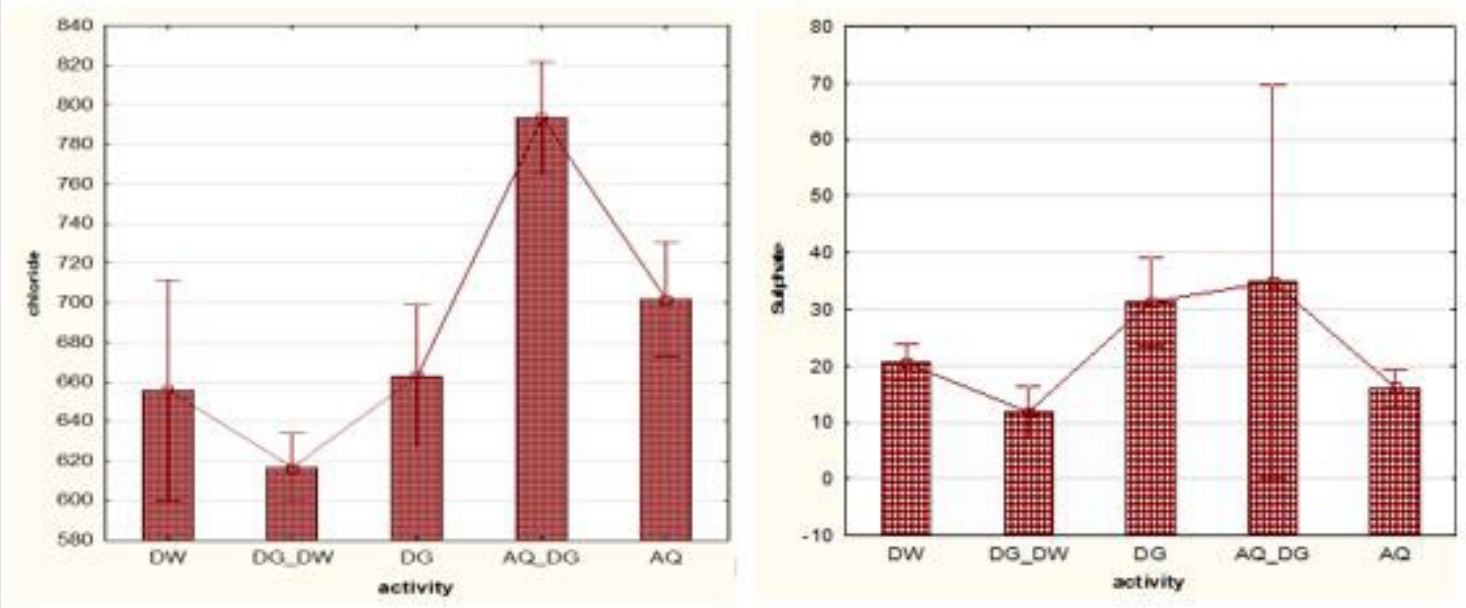

Figure 10: Chloride and Sulphate across the different anthropogenic zones.

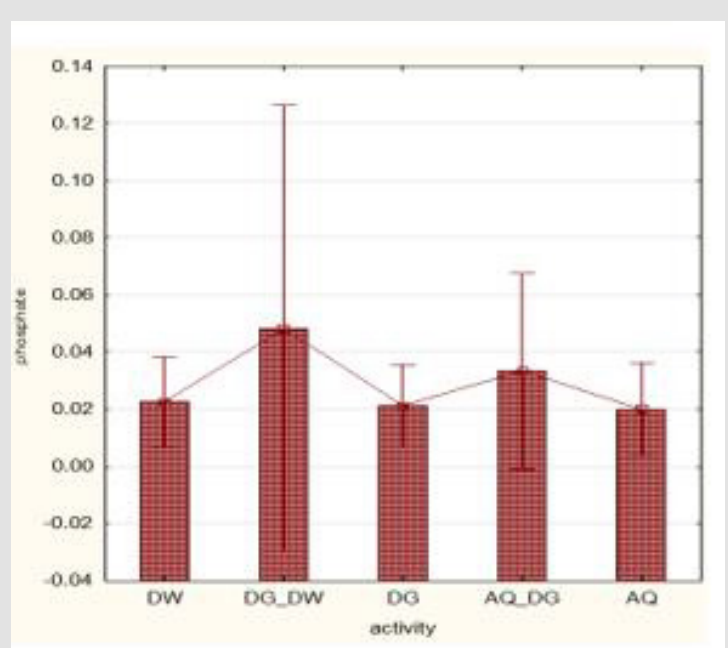

Figure 11: Phosphate Across the different Anthropogenic zones. 


\section{Discussion}

\section{Physico-Chemistry}

The $\mathrm{pH}$ value (7.1-7.8) of the creek was moderately within the range of values reported for rivers flowing through areas with thick vegetation (Uwadaie 2010), it also supported the findings of hydrochemistry of urban creek stated by Edokpayi, et al. [4]. Salinity recorded in this study (2.41-6.66). the salinity value was highest in May 2018 at staton 7 under the AQ_DG zone, the results from this study corroborated the previous reports of other works Edokpayi et al. [6], it confirmed the creek to be brackish. Tidal incursion through the Lagos harbour, run-offs input, and river inflows are major factors controlling the salinity and lagoons of South Western Nigerian Webb [11] (Nwankwo 1988b). High salinity value was recorded in the AQ_DG zone, this inference was due to the closeness of the zone to harbour an indication of sea ingress into the creek. The wet season had higher mean values than dry season, especially the month of May, which is the onset of raining season, therefore there is tidal incursion through the harbour to the creek. The creek was slightly alkaline, the range value was $(20 \mathrm{mg} / \mathrm{L}-80 \mathrm{mg} / \mathrm{L})$, high values of alkalinity was recorded across the different disturbance zone in the month of May 2018, pollution effects from run-offs from municipal, agricultural, and industrial may increase the value of alkalinity Ajao [12].

Biological oxygen demand BOD range value (3.12-4mg), the DW zone had higher value from other zones, this may be accounted for the domestic waste dumpings, sewage dumping in this zone that need oxygen for decomposition [13]. The BOD recorded in this study was lower to the reports of Edokpayi, et al. [4] from Ogbe creek (4.3-9.9mg/L). Nitrate is one of the key nutrients which are utilized by phyto plankton community for their physiological growth and development. The values of Nitrate and Phosphate recorded were generally low compared to reports of other works in Nigerian waters, Epe lagoon Edokpayi, et al. [4]. The low values may be due to the high productivity of primary producer in the creek.

\section{Spatial Distribution of the Macrofauna}

A total of twenty species of benthic macrofauna were obtained during the dry and wet season. The highest number of abundances was registered during the dry season, it decreased during the wet season. This value recorded was low to the forty-two species of benthic macrofauna that were obtained in Lagos lagoon from the reports of Ajao [13], this is indication that there is a level of human disturbance and pollution affecting the benthic macrofauna community in Badagry creek. The class insecta, phylum Arthropoda was not registered during the wet season across the different Anthropogenic zones, probably due to changes in physico chemical parameters, salinity that was high and the water level that increases during the wet season. Higher abundance and occurrence of macro fauna was registered during the dry season, Gastropoda mollusca had $56.02 \%$ and $54.1 \%$ during the dry and wet season respectively, its high abundance was recorded in all the human disturbance zone. However, Gastropods and Bivalves were relatively tolerant to physical and chemical variations in the environment and were present in a broad range of habitats, this result may likely agree with the findings that the specie exhibited less dependency on stable environments and have been recorded to be abundant in various disturbed systems, such as agricultural stream Schafer, et al. $[14,15]$.

Gastropoda were tolerant to all disturbance which may be due to their biological characteristics, filter feeder, this report supported the findings of Ajao [13], that stated that Gastropoda Mollusca emerged as dominant benthic fauna in Lagos Lagoon. The Arthropoda malacostraca had 34.4\% and 28.9\% during wet and dry season. The Mollusca bivalve value was high in wet season $11.43 \%$ and $9.73 \%$ in dry season. The differences in macro benthic fauna occurrence in the different anthropogenic zones in this study have been supported with habitat change and reduction theory Ogbeibu [16]. The Pachymelania and mangrove communities were represented in Badagry creek; P. aurita dominated the member community of Pachymelania community. P. fusca var quadriseriata, Tympanotonus fuscatus var radula, Graphae gasar, Sersama huzardi and T. fuscatus.

\section{Conclusion}

The variances in the number of species and numerical abundance are largely due to physical variability of the study area, the depth of investigation, and the predominant ecological conditions, including the level of contamination from anthropogenic sources of the study area at the time of the surveys. The study revealed that most of the microbenthic fauna occurred seasonal in the water body and the creek could be said to support a wide range of microbenthic invertebrates' species exhibiting different diversity patterns across the anthropogenic zones. This result generated will serve as a checklist data on the seasonal occurrence, composition, and abundance, which will be useful in developing framework for sustainable management of the creek.

\section{References}

1. Pearson TH, Rosenberg R (1978) Macrobenthic succession in relation to organic enrichment and pollution of the marine environment. Oceanogr Mar Biol Annu Rev 16: 229-311.

2. Dauer DM (1993) Biological criteria, environmental-health and estuarine macrobenthic community structure. Mar Pollut Bull 26: 249257.

3. Lotze HK, Lenihan HS, Bourque BJ, Bradbury RH, Cooke RG, et al. (2006) Depletion degradation, and recovery potential of Estuaries and coastal seas. Science pp.1806-1809.

4. Edokpayi CA, Uwadiae RE, Njar CE (2010) Non-insect benthic Phyto macrofauna and organism-water quality relations in a tropical coastal ecosystem: Impact of land-based pollutants. Journal of American Science 6(7): 213-222.

5. Ogunwenmo CA, Osuala IA (2004) Physico-chemical parameters and macrobenthos of an estuarine creek and an artificial pond in Lagos Southwestern, Nigeria. Acta SATECH 1(2): 128-132. 
6. Edokpayi CA, Okenyi JC, Ogbeibu AE, Osimen EC (2000) The effect of human activities on the macrobenthic of Ibiekuma stream, Ekpoma, Nigeria. Bioscience Research communications 12(1): 79-87.

7. Edokpayi CA, Uwadiae RE, Olowopororoku AO (2010) The Hydrochemistry and macrobenthic fauna characteristics of an urban draining creek. Intermational Journal of Biodiversity and Conservation 2(8): 196-203.

8. Southwood TRE, Henderson PA (2000) Ecological Methods ( $3^{\text {rd }}$ Edn.). Wiley-Blackwell, England, pp. 592.

9. (2006) International Standard Organization (ISO). Water qualitysampling- Part 1: Guidance on the design of sampling programmers and sampling techniques. Geneva. ISO Standard 5667-1: 2006.

10. Weigel BM, Dimick JJ (2011) Development, validation, and application of a macroinvertebrate-based Index of Biotic Integrity for nonwadeable rivers of Wisconsin. JN Am Benthol Soc 30: 665-679.

11. Webb JE, Hill MB (1958) Ecology of Lagos Lagoon. III. The life history of Branchiostoma nigrense Webb. Phil Trans Roy Soc Bull 241: 355-391.

\section{ISSN: 2574-1241}

DOI: 10.26717/BJSTR.2021.34.005566

Bosede Omolara Ayo-Dada. Biomed J Sci \& Tech Res

(C) This work is licensed under Creative

Submission Link: https://biomedres.us/submit-manuscript.php
12. Ajao EA, Oyewo E, Unyimadu JP (1996) A review of the pollution of Coastal Waters in Nigeria. Nigeria Institute for Oceanography and Marine Research Technical pp. 107.

13. Ajao EA, Fagade SO (1990) A study of the Sediments and Communities in Lagos Lagoon, Nigeria. Oil \& Chemical pollution 7(2): 85-117.

14. Schäfer RB, Caquet T, Siimes K, Mueller R, Lagadic L, et al. (2007) Effects of pesticides on community structure and ecosystem functions in agricultural streams of three biogeographical regions in Europe. Sci Total Environ. 382(2-3): 272-285.

15. Li Z, Wang J, Liu Z, Meng X, Heino J, et al. (2019) Different responses of taxonomic and functional structures of stream macroinvertebrate communities to local stressors and regional factors in a subtropical biodiversity hot spot. J Science of the total environment 655(2019): 1288-1300.

16. Ogbeibu AE, Oribhabor BJ (2002) Ecological impact of river impoundment using benthic macro invertebrates as indicator. Water Research 36: 2427-2437.

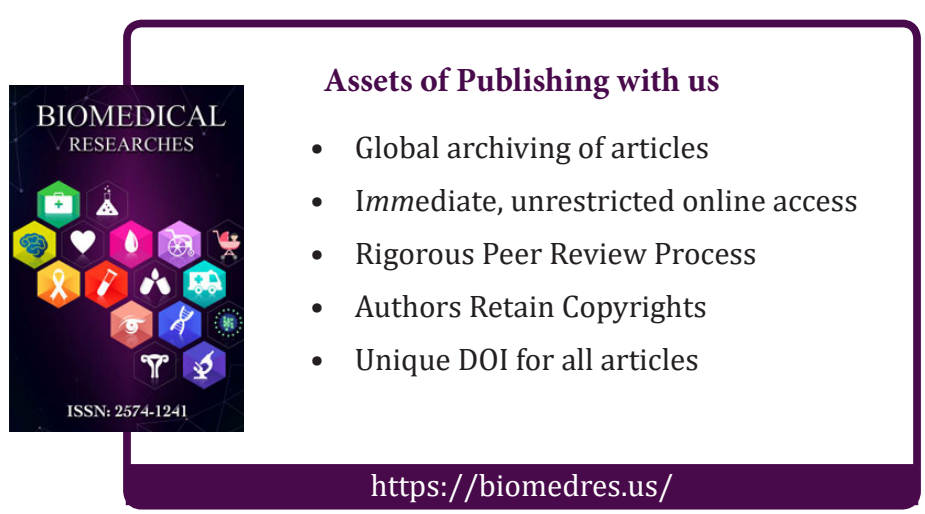

